\title{
Source of bacterial RNA in chronic otitis media with effusion
}

\author{
P.-Z. Li, L. Cheng and M.-L. Qiu \\ Department of Otolaryngology, Huai'an First People's Hospital, \\ Nanjing Medical University, Huai'an, Jiangsu, China \\ Corresponding author: L. Cheng \\ E-mail: leichengcn@163.com \\ Genet. Mol. Res. 13 (3): 6093-6098 (2014) \\ Received July 29, 2013 \\ Accepted January 10, 2014 \\ Published August 7, 2014 \\ DOI http://dx.doi.org/10.4238/2014.August.7.24
}

ABSTRACT. The purpose of this study was to investigate whether the bacterial RNA detected by polymerase chain reaction (PCR) and reverse transcription (RT)-PCR methods in middle ear effusion (MEE) for pediatric chronic otitis media with effusion (OME) originated from live bacteria. Degradation of RNA was observed by spectroscopic analysis; we also investigated the effect of MEE on the digestive activity of RNase. The optical density of RNA solution was stable within $3 \mathrm{~h}$. MEE could not degrade the RNA, while RNase could rapidly digest the RNA. MEE significantly inhibited the digestive activity of RNase, and the inhibitory effect was correlated with MEE concentration. The bacterial DNA and RNA detected by PCR and RT-PCR methods may not originate from live bacteria, but might instead originate from residues from previous bacterial infection(s). Chronic OME is not an infection of live bacteria, and therefore, antibiotics should be used with caution for clinical treatment of pediatric chronic OME.

Key words: Chronic otitis media with effusion; Middle ear effusion; RNA; Optical density 


\section{INTRODUCTION}

Chronic otitis media with effusion (OME) is defined as the presence of fluid in the middle ear without symptoms or signs of infection and is the most common cause of acquired hearing loss in childhood. Thus, this condition can result in the developmental impairment of linguistic, behavioral, motor, and social skills (de Miguel Martinez and Macias, 2008; Serbetcioglu et al., 2008; Eser et al., 2009). The causes of OME include bacterial and viral infections, allergic reaction, and Eustachian tube dysfunction (Keles et al., 2005). It has been confirmed by standard bacterial culture methods that bacteria can be cultivated in middle ear effusion (MEE) in only $40 \%$ of children with OME. However, some studies using polymerase chain reaction (PCR) and reverse transcription (RT)-PCR methods found at least one type of pathogen in most MEE cases, and that OME is a type of bacterial infection (Tano et al., 2008; Guvenc et al., 2010).

The Gram-positive bacteria Alloiococcus otitidis is thought to play an important role in the etiology of otitis media and OME. Using a multiplex PCR method, the detection rate of $A$. otitidis is higher than that of Haemophilus influenzae and Streptococcus pneumoniae (Kalcioglu et al., 2002; Leskinen et al., 2002; Harimaya et al., 2006a,b; Kaur et al., 2010). However, the PCR system is very sensitive and only requires small DNA fragments for amplification. Thus, detecting bacterial DNA and RNA in MEE does not necessarily indicate infection with live bacteria. These DNA and RNA may instead represent previous bacterial infection(s) or their residues.

In this study, the degradation of RNA in MEE was evaluated and the inhibitory effect of MEE on RNase was investigated. The goal of this study was to clarify whether RNA detected in MEE is from live bacteria.

\section{MATERIAL AND METHODS}

\section{Preparation of MEE}

One hundred Chinese children (74 males and 26 females) with chronic OME were enrolled in this study at Huai'an First People's Hospital, Nanjing Medical University from July 2010 through December 2011. Their ages were 1-14 years, with an average age of 4.5 years. This study was conducted in accordance with the Declaration of Helsinki. This study was conducted with approval from the Ethics Committee of Huai'an First People's Hospital.

The course of disease in each patient was more than 3 months. The external auditory canal was cleansed with $75 \%$ ethanol solution and then myringotomy was performed with a paracentesis knife under general anesthesia. The MEE specimen was obtained and was stored at $-20^{\circ} \mathrm{C}$ until use. When conducting the following experiments, the specimen was melted at room temperature and then flushed out of the collection tube using $0.1 \mathrm{M}$ acetate buffer solution, $\mathrm{pH}$ 5.0. The mixture was homogenized for $1 \mathrm{~min}$ in Silvenson homogenizer to obtain a uniform liquid.

\section{Observation of RNA degradation}

The optical density of the RNA solution was determined at $25^{\circ} \mathrm{C}$ and $300 \mathrm{~nm}$ in a PU 8625 UV/Vis spectrophotometer (Philips Company, Cambridge, England). Acetate buffer solution and distilled water were used as blank controls. A decrease in optical density represented RNA degradation. 


\section{MEE digestive activity on RNA}

To evaluate the MEE digestive activity on RNA, $0,0.5$, and $1 \mathrm{~mL}$ homogenized MEE was added to 3, 2.5, and $2 \mathrm{~mL}$ RNA solution (RNA, $2 \mathrm{mg}$; solvent, acetate buffer solution), respectively. The change in optical density in the mixture within $3 \mathrm{~h}$ was observed.

\section{RNase digestive activity on RNA and MEE}

To determine the RNase digestive activity on RNA and MEE, $0.5 \mathrm{~mL}$ acetate buffer solution was added to $2 \mathrm{~mL}$ RNA solution. In addition, $0.1,0.2,0.3,0.4$, and $0.5 \mathrm{~mL}$ homogenized MEE was added to $2 \mathrm{~mL}$ acetate buffer solution, followed by addition of $2 \mathrm{~mL}$ RNase (5 U). The total volume of the mixture was adjusted to $4.5 \mathrm{~mL}$ with acetate buffer solution. The change in optical density in the mixture within $3 \mathrm{~h}$ was recorded.

\section{Effect of MEE on the digestive activity of RNase}

To determine the effect of MEE on the digestive activity of RNase, $0.1,0.2,0.3,0.4$, and $0.5 \mathrm{~mL}$ homogenized MEE was added to $2 \mathrm{~mL}$ RNA solution, followed by addition of 2 $\mathrm{mL}$ RNase. The change in optical density in the mixture within $3 \mathrm{~h}$ was recorded.

\section{Effect of ethylenediaminetetraacetic acid (EDTA) on the digestive activity of RNase}

For this assay, $0.05,0.1$, and $0.5 \mathrm{~mm}$ EDTA was added to $2 \mathrm{~mL}$ bacterial RNA solution, followed by addition of $2 \mathrm{~mL}$ RNase. The change in optical density in the mixture within $3 \mathrm{~h}$ was recorded.

\section{Statistical analysis}

Data were analyzed using SPSS ver. 19 (SPSS, Inc., Chicago, IL, USA), and the difference between the groups was compared using the Student $t$-test. A P-value less than 0.05 was considered to be statistically significant.

\section{RESULTS}

\section{MEE digestive activity on RNA}

The optical density of RNA solution was relatively stable within $3 \mathrm{~h}$, showing only a $0.95 \%$ decrease. After addition of 0.05 and $1 \mathrm{~mL}$ MEE, the optical density remained stable, showing decreases of 1.5 and $7.6 \%$, respectively. This indicates that the RNA solution was stable within $3 \mathrm{~h}$.

After adding RNase to the bacterial RNA solution, the optical density decreased rapidly by $87.4 \%$ within $3 \mathrm{~h}$, indicating that RNase could degrade the bacterial RNA. However, after 0.1-0.5 mL homogenized MEE were added to the bacterial RNA solution, the optical density remained stable, showing decreases of only $12.6,9.1,6.6,4.5$, and $2.2 \%$ within $3 \mathrm{~h}$, respectively. This suggests that MEE could not degrade RNA and it had no RNase activity 
(Table 1). Statistical analysis revealed that the difference between groups was not significant $(\mathrm{P}>0.05)$.

Table 1. Middle ear effusion (MEE) digestive activity on RNA.

\begin{tabular}{lccccc}
\hline MEE & $0.1 \mathrm{~mL}$ & $0.2 \mathrm{~mL}$ & $0.3 \mathrm{~mL}$ & $0.4 \mathrm{~mL}$ & $0.5 \mathrm{~mL}$ \\
\hline Digestive activity & $12.6 \%$ & $9.1 \%$ & $6.6 \%$ & $4.5 \%$ & $2.2 \%$ \\
\hline
\end{tabular}

\section{Effect of MEE on the inhibition activity of RNase}

When RNase was added to the bacterial RNA solution containing different amounts of MEE, the optical density of the mixture also decreased, but the degree of the decrease was significantly less than that of the RNA solution without MEE. In addition, $0.1 \mathrm{~mL}$ MEE showed no inhibitory activity on RNase, but $0.2-0.5 \mathrm{~mL}$ MEE inhibited RNase activity by $37.8,44.3,63.4$, and $83.8 \%$, respectively. After dialysis, inhibition was $24.5,46.1,62.7,72.6$, and $89.3 \%$, respectively, which were similar to the non-dialysis values. This indicates that MEE significantly inhibited the digestion activity of RNase and that the inhibitory effect was related to MEE concentration. In addition, EDTA showed a clear inhibitory effect on RNase; $0.5 \mathrm{mM}$ EDTA inhibited activity by $87.7 \%$, which was similar to the effect of $0.5 \mathrm{~mL}$ MEE (Table 2). Statistical analysis showed that the difference between groups was very significant $(\mathrm{P}<0.01)$.

Table 2. Effect of middle ear effusion (MEE) on inhibition activity of RNase.

\begin{tabular}{lccccc}
\hline MEE & $0.1 \mathrm{~mL}$ & $0.2 \mathrm{~mL}$ & $0.3 \mathrm{~mL}$ & $0.4 \mathrm{~mL}$ & $0.5 \mathrm{~mL}$ \\
\hline Inhibition activity & $0 \%$ & $37.8 \%$ & $44.3 \%$ & $63.4 \%$ & $83.8 \%$ \\
\hline
\end{tabular}

\section{DISCUSSION}

OME is an MEE disease without acute infection in the tympanum or mastoid. Pediatric OME can result in hearing loss, thus affecting language learning (Post et al., 1995). OME occurs in more than $50 \%$ of infants overall during the first year of life (Rosenfeld et al., 2004). PCR is a sensitive method for detecting bacterial DNA, requiring only small DNA fragments for amplification. It is thought that detection of bacterial DNA by PCR only represents the presence of live bacteria (Post et al., 1996; Hendolin et al., 2000; Holder et al., 2012). Studies involving PCR have shown that bacterial DNA exists in some MEE samples. Thus, OME is considered to be a bacterial infection (Paradise et al., 1997). Rayner et al. (1998) confirmed the existence of bacterial mRNA in MEE using RT-PCR. This is considered as evidence of a bacterial infection.

A. otitidis can be detected in the external auditory canal, nasopharynx, and maxillary sinus of normal individuals, whereas it is also detected in the middle ear cavity of patients. This indicates that $A$. otitidis may be part of the normal flora found in the external auditory canal. A. otitidis in the middle ear cavity may originate in the external auditory canal that be- 
comes polluted during myringotomy, and is likely not the pathogen causing OME (Durmaz et al., 2002; Kalcioglu et al., 2003; De Baere et al., 2010).

In this study, we found that the bacterial RNA solution was stable within $3 \mathrm{~h}$. After adding 0.05 and $1 \mathrm{~mL}$ MEE, the optical density in the bacterial RNA solution showed only a slight decrease. This is in contrast to the traditional view that the half-life of RNA is only a few seconds to several minutes. Thus, MEE appears to have no RNase activity. However, after RNase was added to the bacterial RNA solution, the optical density decreased rapidly, showing an $87.4 \%$ decrease within $3 \mathrm{~h}$. This indicates that RNase can quickly degrade RNA. When RNase was added to the bacterial RNA solution containing MEE, the decrease in optical density was less than that observed in the RNA solution without MEE. The inhibitory effect of 0.5 $\mathrm{mL}$ MEE was similar to that of $0.5 \mathrm{mM}$ EDTA, indicating that MEE could significantly inhibit the digestive activity of RNase and that the inhibitory effect is related to MEE concentration. Bacterial mRNA in MEE, similar to DNA, may be present from a previous bacterial infection. This RNA is protected from degradation by MEE.

The bacterial DNA and RNA detected by PCR and RT-PCR methods may not originate from live bacteria, but are rather the residues from previous infection. These results indicate that chronic OME is not an infection of live bacteria, and antibiotics should be used with caution for clinical treatment of pediatric chronic OME.

\section{REFERENCES}

De Baere T, Vaneechoutte M, Deschaght P, Huyghe J, et al. (2010). The prevalence of middle ear pathogens in the outer ear canal and the nasopharyngeal cavity of healthy young adults. Clin. Microbiol. Infect. 16: 1031-1035.

de Miguel Martinez I and Macias AR (2008). Serous otitis media in children: implication of Alloiococcus otitidis. Otol. Neurotol. 29: 526-530.

Durmaz R, Ozerol IH, Kalcioglu MT, Oncel S, et al. (2002). Detection of Alloiococcus otitidis in the nasopharynx and in the outer ear canal. New Microbiol. 25: 265-268.

Eser OK, Ipci K, Alp S, Akyol U, et al. (2009). Efficacy of nasopharyngeal culture in identification of pathogen in middle ear fluid in chronic otitis media with effusion. Indian J. Med. Microbiol. 27: 237-241.

Guvenc MG, Midilli K, Inci E, Kuskucu M, et al. (2010). Lack of Chlamydophila pneumoniae and predominance of Alloiococcus otitidis in middle ear fluids of children with otitis media with effusion. Auris Nasus Larynx. 37: 269-273.

Harimaya A, Takada R, Hendolin PH, Fujii N, et al. (2006a). High incidence of Alloiococcus otitidis in children with otitis media, despite treatment with antibiotics. J. Clin. Microbiol. 44: 946-949.

Harimaya A, Takada R, Somekawa Y, Fujii N, et al. (2006b). High frequency of Alloiococcus otitidis in the nasopharynx and in the middle ear cavity of otitis-prone children. Int. J. Pediatr. Otorhinolaryngol. 70: 1009-1014.

Hendolin PH, Paulin L and Ylikoski J (2000). Clinically applicable multiplex PCR for four middle ear pathogens. J. Clin. Microbiol. 38: 125-132.

Holder RC, Kirse DJ, Evans AK, Peters TR, et al. (2012). One third of middle ear effusions from children undergoing tympanostomy tube placement had multiple bacterial pathogens. BMC Pediatr. 12: 87.

Kalcioglu MT, Oncel S, Durmaz R, Otlu B, et al. (2002). Bacterial etiology of otitis media with effusion; focusing on the high positivity of Alloiococcus otitidis. New Microbiol. 25: 31-35.

Kalcioglu MT, Durmaz B, Aktas E, Ozturan O, et al. (2003). Bacteriology of chronic maxillary sinusitis and normal maxillary sinuses: using culture and multiplex polymerase chain reaction. Am. J. Rhinol. 17: 143-147.

Kaur R, Adlowitz DG, Casey JR, Zeng M, et al. (2010). Simultaneous assay for four bacterial species including Alloiococcus otitidis using multiplex-PCR in children with culture negative acute otitis media. Pediatr. Infect. Dis. J. 29: 741-745.

Keles B, Ozturk K, Arbag H, Gunel E, et al. (2005). Frequency of pharyngeal reflux in children with adenoid hyperplasia. Int. J. Pediatr. Otorhinolaryngol. 69: 1103-1107.

Leskinen K, Hendolin P, Virolainen-Julkunen A, Ylikoski J, et al. (2002). The clinical role of Alloiococcus otitidis in otitis media with effusion. Int. J. Pediatr. Otorhinolaryngol. 66: 41-48.

Paradise JL, Rockette HE, Colborn DK, Bernard BS, et al. (1997). Otitis media in 2253 Pittsburgh-area infants: prevalence and risk factors during the first two years of life. Pediatrics 99: 318-333. 
Post JC, Preston RA, Aul JJ, Larkins-Pettigrew M, et al. (1995). Molecular analysis of bacterial pathogens in otitis media with effusion. JAMA 273: 1598-1604.

Post JC, Aul JJ, White GJ, Wadowsky RM, et al. (1996). PCR-based detection of bacterial DNA after antimicrobial treatment is indicative of persistent, viable bacteria in the chinchilla model of otitis media. Am. J. Otolaryngol. 17: 106-111.

Rayner MG, Zhang Y, Gorry MC, Chen Y, et al. (1998). Evidence of bacterial metabolic activity in culture-negative otitis media with effusion. JAMA 279: 296-299.

Rosenfeld RM, Culpepper L, Doyle KJ, Grundfast KM, et al. (2004). Clinical practice guideline: Otitis media with effusion. Otolaryngol. Head Neck Surg. 130: S95-118.

Serbetcioglu B, Ugurtay O, Kirkim G and Mutlu B (2008). No association between hearing loss due to bilateral otitis media with effusion and Denver-II test results in preschool children. Int. J. Pediatr. Otorhinolaryngol. 72: 215-222.

Tano K, von Essen R, Eriksson PO and Sjostedt A (2008). Alloiococcus otitidis - otitis media pathogen or normal bacterial flora? APMIS 116: 785-790. 